ANUARIo De Estudios Medievales

51/1, enero-junio de 2021, pp. 73-100

ISSN 0066-5061

https://doi.org/10.3989/aem.2021.51.1.03

\title{
EL PONTIFICADO BAJOMEDIEVAL Y LOS OBISPOS HISPANOS. LUCHAS DE PODER POR LA COLACIÓN DE BENEFICIOS ECLESIÁSTICOS AL COMIENZO DEL PAPADO DE AVIÑÓN
}

\author{
THE LATE MEDIEVAL PONTIFICATE AND HISPANIC BISHOPS. \\ POWER STRUGGLES FOR THE COLLATION OF ECCLESIASTICAL BENEFITS \\ AT THE BEGINNING OF THE AVIGNON PAPACY
}

\author{
SANTIAGo DOMÍNGUEZ SÁNCHEZ \\ Universidad de León \\ https://orcid.org/0000-0002-5099-6307
}

\begin{abstract}
Resumen: A comienzos del siglo XIV, con el traslado de la sede pontificia desde Roma hasta Aviñón, se produjeron numerosos cambios en la Iglesia que llevaron a un control mucho más exhaustivo de la presión fiscal y de la colación de los beneficios eclesiásticos de toda la Cristiandad por parte del propio papa, a favor en muchos casos de clérigos franceses próximos a él mismo. A la vez, como es sabido, en el año 1311, en el Concilio de Vienne, se decretó la supresión de la orden militar de los templarios, y ello dio lugar a que numerosas iglesias que antiguamente pertenecían a esta orden militar ahora fuesen controladas directamente por el papado, que nombraba a sus clérigos. Todo ello produjo un enfrentamiento importante con los obispos locales hispanos, que ahora se estudia con detenimiento.
\end{abstract}

Palabras clave: Pontificado medieval; papado de Aviñón; luchas de poder; obispos medievales.

Abstract: In the early $14^{\text {th }}$ century, with the transfer of the pontifical court from Rome to Avignon, the numerous changes occurring in the Church led to a new and far-reaching control executed by the Pope himself over fiscal pressure and the collation of ecclesiastical benefices across Christendom, in many cases in favour of French clerics who were close to papal court. At the same time, as is widely known, in the year 1311, the military order of the Templars was officially dissolved at the Council of Vienne, and numerous churches which previously belonged to the order came under the direct control of the Papacy, which named their clergy. This whole situation triggered serious confrontations with the local Hispanic bishops, which are studied in depth in this article.

Keywords: Medieval pontificate; Avignon papacy; power struggles; medieval bishops.

\section{SUMARIO}

1. Introducción.- 2. La Iglesia a comienzos del siglo XIV.- 3. El pontificado en Aviñón.- 4. La fiscalidad en el papado de Aviñón.- 5. La colación directa de beneficios por el papado y la oposición episcopal.- 6. La supresión del Temple y la colación por el papado de las iglesias anteriormente templarias. Rechazo de los obispos hispanos.7. A modo de conclusión.- 8. Bibliografía citada. 


\section{INTRODUCCIÓN}

Este artículo intenta presentar un marco histórico a este número monográfico que los lectores tienen en sus manos, o al menos a uno de sus aspectos, el referido al poder episcopal en la Península Ibérica durante la Baja Edad Media y a la tensión que tuvo con otros poderes, especialmente con el papal, en la colación de beneficios eclesiásticos. No pretende ni realizar una discusión sobre el estado de la cuestión, ni revisar la cuantiosa bibliografía, antigua y reciente, que existe sobre el tema. Las primeras páginas de este trabajo buscan situar en su ámbito y presentar de modo sencillo los cambios enormes que supuso el establecimiento del papado en Aviñón, especialmente en lo relativo al control centralista de la concesión de prebendas y de la fiscalidad por parte de la Iglesia.

Nuestra intención es ofrecer un abanico de posibilidades de estudio del tema en cuestión, sólidamente fundamentadas en documentos, que queden abiertas para futuros trabajos. El aprovechamiento que podría hacerse de los cientos de diplomas pontificios en los que nos basamos para nuestro estudio daría para más de una tesis doctoral, por lo que ahora creemos inviable profundizar mínimamente en ellos. Pero también parece de interés su selección y presentación crítica a otros investigadores, como modo de abrirles líneas de investigación fundamentadas en datos heurísticos contrastados.

\section{LA IGLESIA A COMIENZOS DEL SIGLO XIV}

Permítansenos comenzar este artículo con unas palabras de José Orlandis que sitúan perfectamente el contexto en que está la Iglesia en este momento ${ }^{1}$ :

Los comienzos del siglo XIV, en los que puede situarse el comienzo de la Baja Edad Media, señalan también el principio de una nueva época en la vida de la Iglesia. Este período que ahora se abre presenta unos rasgos muy distintos del anterior, que ha sido llamado "la Cristiandad medieval". Bajo muchos aspectos podría incluso considerarse un tiempo de decadencia, aunque será mejor decir simplemente que fue un período en el cual se puso de manifiesto en diversos terrenos una crisis muy profunda. Esta crisis afectó de modo particular al pontificado, cuyo prestigio sufrió tan rudas pruebas que hasta llegó a ponerse en entredicho su autoridad suprema dentro de la propia Iglesia (...). Esta, en la hora final de la Edad Media, parecía carecer del dinamismo espiritual

\footnotetext{
${ }^{1}$ Orlandis 1989, p. 371.
} 
que hacía falta para afrontar los tiempos modernos y los grandes cambios que el mundo estaba a punto de sufrir.

Hasta el pontificado de Bonifacio VIII, a caballo entre finales del siglo XIII y principios del XIV (1294-1303), se había mantenido en vigor lo que se ha denominado el absolutismo teocrático, esto es, una concepción y un sistema de gobierno en el que no se dudaba de que el pontífice, como representante de Cristo en la tierra, gozaba de los máximos poderes también en el ámbito que hoy llamaríamos político. Efectivamente, el papa en la segunda mitad del siglo XI, o durante los siglos XII y XIII, era la máxima autoridad política, con un poder y una jurisdicción que se consideraban emanados de Dios, que ejercía en muchas ocasiones por encima del poder de los numerosos reyes y príncipes europeos.

Pero el siglo XIII finaliza con un lamentable pontificado, el del referido Bonifacio VIII (1294-1303), en el que se mantuvo una dura pugna entre el tradicional absolutismo teocrático medieval y el absolutismo monárquico, representado por el rey de Francia, Felipe IV el Hermoso (1285-1314), que finalmente se dirimió en favor de este último².

No está de más recordar en un artículo como este, dedicado a cuestiones de fiscalidad y colación de beneficios eclesiásticos, que precisamente el motivo de los graves enfrentamientos entre Bonifacio VIII y Felipe IV el Hermoso de Francia estuvo en una cuestión fiscal. Dicho soberano, al darse cuenta de que la hacienda real estaba absolutamente esquilmada debido a las luchas con Inglaterra por la posesión de La Aquitania y La Gascuña, comenzó a cobrar tributos a iglesias y monasterios. A Bonifacio VIII le pareció que esto atentaba contra los derechos sagrados de la Iglesia y hacía competencia a los recaudadores pontificios, por lo que en 1296 dictó la bula Clericis lai$\cos ^{3}$, prohibiendo tajantemente a reyes, príncipes y otras autoridades de toda la Cristiandad imponer cualquier tasa a los eclesiásticos.

Algunos reinos, como Inglaterra, Castilla o Aragón, acataron la disposición, pero Felipe IV de Francia respondió expulsando a los recaudadores pontificios y prohibiendo pagar tributos a Roma. Aunque Bonifacio VIII en parte dio marcha atrás, a partir de entonces las relaciones con el rey de Francia fueron muy conflictivas ${ }^{4}$. Desde 1301, con motivo de la detención del obispo de Pamiers por el monarca, la situación se complicó. Felipe el Hermoso prohibió toda relación de los prelados franceses con Roma y declaró solemnemente que en cuestiones temporales no se sometía a nadie, ni siquiera al pontífice.

\footnotetext{
${ }^{2}$ Sobre este asunto, $c f$. los estudios clásicos de Rivière 1926; Curley 1927.

${ }^{3}$ Cf. Domínguez 2006, doc. 212.

${ }^{4}$ Cf. la monografía conocida de Bambauer 1920.
} 
Este llamó a Roma a los prelados franceses y al rey. Se presentaron en la curia 39 obispos, desafiando la prohibición real y, ante ellos, en noviembre de 1302, el papa dictó la constitución Unam sanctam, que pretendía imponer la primacía absoluta del pontífice tanto en el terreno espiritual como en el temporal. Entonces Felipe IV, en el verano de 1303, formuló gravísimas y, en su mayoría, falsas acusaciones contra Bonifacio VIII. El consejero del rey, Guillaume de Nogaret, los poderosos nobles Colonna y otras tropas italianas asaltaron la ciudad de Anagni apresando al pontífice el 7 de septiembre de 1303. Aunque dos días después el pueblo de Anagni rescató al papa de las manos de los franceses, y el día 25 de dicho mes Bonifacio VIII regresó a Roma, el golpe moral recibido fue tal que, dos semanas más tarde, el 11 de octubre de 1303, el papa fallecía. Felipe el Hermoso no olvidó nunca, como veremos, su rencor hacia Bonifacio VIII y tuvo siempre como objetivo no sólo conseguir una monarquía francesa universal, sino también lograr una humillación solemne del difunto papa ${ }^{5}$.

El estado tenderá, desde la época de Felipe el Hermoso, al regalismo y absolutismo propios de la Edad Moderna. En el comienzo del siglo XIV hay que situar este punto de inflexión, en el que ya se ven algunos aspectos del estado moderno. Supone claramente el fin casi definitivo de una concepción medieval en la que la máxima autoridad residía en el pontífice, como supremo representante de Dios. El establecimiento por Clemente V del papado en Aviñón y el ulterior Cisma de Occidente no hicieron más que ratificar el nacimiento de unos tiempos nuevos, en los que el poder de las coronas, desvinculadas paulatinamente de la tutela de la Iglesia, será cada vez más absoluto ${ }^{6}$.

\section{EL PONTIFICADO EN AVIÑÓN}

Conviene detenerse en el inicio del pontificado clave de Clemente V. Tras la muerte en julio de 1304 de Benedicto XI, que había gobernado la Iglesia durante menos de un año, los cardenales, reunidos en cónclave en Perugia, designaron como nuevo pontífice al arzobispo de Burdeos, Bertrand de Got, el 5 de junio de 1305, tras once meses de tensas deliberaciones entre los purpurados franceses y los italianos. Este tomó el nombre de Clemente V. Había nacido en La Gascuña, en la localidad de Villandraut, en 1264. Estudió

\footnotetext{
${ }^{5}$ El rey quería que el nombre de Bonifacio fuese retirado de la lista de papas como un hereje, sus restos desenterrados y quemados y las cenizas esparcidas al viento. Intentó durante varios años conseguirlo, aunque finalmente sólo logró que el papado reconociera que el monarca francés no había tenido culpa alguna en sus reyertas con el papa Bonifacio VIII.

${ }^{6} C f$. Lagarde 1934.
} 
“Artes" (Letras) en Toulouse y Derecho canónico y civil en Orléans y Bolonia. Fue designado obispo de Comminges por Bonifacio VIII en el año 1295 $\mathrm{y}$, finalmente, arzobispo de Burdeos, entonces un cargo comprometido debido a su situación en la Aquitania inglesa y al largo conflicto con el reino franco.

Clemente V fue coronado papa en Lyon el 14 de noviembre de 1305 $\mathrm{y}$, a pesar de que manifestó su deseo de ir a Roma ${ }^{7}$, nunca lo hizo en los casi nueve años de su pontificado. Un gran apego por su Francia natal y un gran miedo ante la situación de anarquía de Roma y de los Estados Pontificios fueron fatídicos para el pontificado. Durante más de setenta años los papas residirían en Francia y, a partir de 1309, en la ciudad de Aviñón ${ }^{8}$. Quizá como consecuencia de esta elección de sede, Clemente V, al igual que sus sucesores, estuvo durante su pontificado sometido a los poderosos reyes franceses, comenzando por el enérgico y ya citado Felipe IV el Hermoso (1286-1314). Clemente $\mathrm{V}$, en una curiosa maniobra de giro completo con respecto a lo que había sucedido en época de su predecesor, Bonifacio VIII, consideró a los reyes francos como el brazo secular del papado. Ya en el documento pontificio de coronación, dirigido a todos los reyes y grandes prelados de la Cristiandad ${ }^{9}$, Clemente $\mathrm{V}$ destacaba nominalmente al rey francés, sin hacer alusión alguna a los demás soberanos. Fue el comienzo de un error que le perseguiría durante toda su vida. Como también afirma el profesor Orlandis,

lejos de Roma, la Sede apostólica perdió universalidad, se afrancesó y fue víctima de un aldeano espíritu localista que rebajó la autoridad del pontificado. Los datos estadísticos correspondientes al período aviñonés hablan por sí solos: fueron franceses los siete papas que se sucedieron en él; pero hubo más todavía: de los 134 cardenales creados durante estos pontificados, 113 eran franceses y de entre ellos las tres cuartas partes originarios del mediodía de Francia $^{10}$.

Los cardenales que eligieron en Perugia a Bertrand de Got deseaban evidentemente complacer al todopoderoso rey francés. Sin embargo, el conocido relato de Giovanni Villani sobre una decisiva influencia de Felipe IV el Hermoso en su elección y la conferencia secreta del nuevo papa con él a

\footnotetext{
${ }^{7}$ Parece que deseaba esperar antes de ir a Roma a que se alcanzase la paz entre los reyes de Francia e Inglaterra y a que se hubiera organizado la Cruzada, objetivo este último proclamado con elocuentes frases en su documento de coronación. Sobre el itinerario de Clemente V, por otro lado, véase un buen resumen en Schenk 1979, pp. 192 y ss.

${ }^{8}$ Cf. Guillemain 1998.

${ }^{9}$ Domínguez 2014, docs. 23-24.

${ }^{10}$ Orlandis 1989, pp. 372-373.
} 
todas luces carece de valor histórico ${ }^{11}$. Además, como arzobispo de Burdeos, Bertrand de Got era realmente súbdito del rey de Inglaterra, aunque desde su juventud había sido amigo personal de Felipe el Hermoso ${ }^{12}$.

El establecimiento de la Sede Pontificia en Aviñón, decidido en agosto de 1308 y llevado a cabo en marzo de $1309^{13}$, se debió a que esta ciudad reunía para el nuevo papa unas ventajas difíciles de superar: sus comunicaciones con Italia eran muy fáciles; era vecina de Francia, pero no dependía de ella, al estar sometida a los príncipes angevinos de Nápoles, vasallos a su vez de la Sede Apostólica; y, además, las condiciones estratégicas de la urbe eran excelentes. Clemente $\mathrm{V}$ no decidió en un primer momento construir el palacio pontificio de Aviñón que hoy conocemos, sino que se contentó con vivir modestamente en el convento de los dominicos de esta ciudad ${ }^{14}$.

Las investigaciones sobre el papado de Clemente $\mathrm{V}$ y, en general, sobre el pontificado de Aviñón, son abundantísimas, especialmente entre historiadores franceses desde mediados del siglo XIX ${ }^{15}$. Todos ellos destacan una cualidad de Clemente $\mathrm{V}$, continuada por los demás pontífices aviñoneses: la perfecta y complicada maquinaria administrativa que desarrollaron y que logró controlar hasta los mínimos y más escondidos resortes de la gestión eclesiástica de gran parte de la Cristiandad, entre ellos, el relativo a la colación de numerosos beneficios eclesiásticos.

De hecho, Clemente V prosiguió la tarea de centralización desarrollada desde fines del siglo XI por sus antecesores, logrando un alto grado de perfección en la efectiva gestión de un gobierno único, en el que los dicasterios de la curia estaban magistralmente organizados.

Como consecuencia, Clemente V consiguió reservar para su curia la resolución de numerosísimos asuntos propios de los obispados de toda la Cristiandad. Se ha reseñado la admirable organización administrativa y el eficaz funcionamiento de la burocracia pontificia, plasmada en muchos miles de diplomas expedidos desde la cancillería, la penitenciaría, la audiencia, la cámara, las oficinas de los cardenales, etc. Recuérdese, en este sentido, el número de 1420

${ }^{11} C f$. Raynaldo 1747, documentación del año 1305, caps. 2-4.

${ }^{12}$ Y había permanecido fiel a Bonifacio VIII, el pontífice con quien el rey francés, como dijimos más arriba, había estado enfrentado durísimamente.

${ }_{13}^{13}$ Domínguez 2014, docs. 422-538, 586-691, 696, 699, 735, 746, 758-834, 836-838, 879, 923-926, 1114-1179, 1181-1227, 1261.

${ }^{14}$ Clemente V llevó una vida personal presidida por la sencillez, pero enriqueció notablemente a sus familiares. Valga este dato: dejó en su testamento 315.000 florines de oro a sus familiares y otros 300.000 (nada menos que $1061 \mathrm{~kg}$. de oro) a su sobrino Bertrand, vizconde de Lomagne, pero tan sólo 70.000 a su sucesor (Juan XXII). Cf. Ehrle 1888.

${ }^{15}$ Nos han sido útiles los estudios de Lizerand 1910; Berger 1910; Mollat 1921, 1949; Bernard 1949; Renouard 1954; Schenk 1979; Guillemain 1962, 1998; Paladilhe 1979; Pujol 1988; Nieto 1988, 1996; Mossé, Pallanchard 1998; Favier 2006. 
diplomas expedidos por esta maquinaria burocrática pontificia hacia los reinos de la Península Ibérica, que es al menos el doble de la media de los pontífices del siglo precedente ${ }^{16}$. En este artículo nos centraremos en un estudio profundo de algunas de estas cartas papales, que nos mostrará palpablemente aspectos interesantísimos sobre las luchas de poder entre el papado y los obispos hispanos, entre otras muchas cosas, por la colación de los beneficios eclesiásticos.

\section{LA FISCALIDAD EN EL PAPADO DE AVIÑÓN}

La curia romana, como decimos, gestionaba todo tipo de asuntos de las iglesias particulares, pero especialmente tenía un fin: conseguir que un alto porcentaje de los beneficios eclesiásticos pasaran a ser provisión directa de ella misma ${ }^{17}$.

Como es sabido, a partir del siglo XI la Iglesia se había conseguido independizar del poder laico en lo referente a la provisión de sus beneficiados, introduciendo la elección canónica como sistema ordinario en la provisión de la mayor parte de los cargos eclesiásticos, al menos de los principales. La situación cambió cuando en 1265 Clemente IV sentó el principio de que el pontífice, como jefe supremo de la Iglesia, tenía poder de disposición sobre todos los beneficios, como consecuencia de lo cual se reservó las llamadas "vacantes en la curia", esto es, aquellos beneficios que hubieran quedado vacantes por fallecimiento de su titular en la Sede Apostólica, en sus cercanías, o estando de camino de ida o de regreso de la misma ${ }^{18}$.

Clemente V, y más aún sus sucesores, ampliaron esta reserva pontificia, por lo que el número de beneficios que se reservaban al pontífice se hizo cada vez mayor. De hecho, los últimos papas de Aviñón extendieron tal reserva pontificia a todos los beneficios eclesiásticos mayores, por lo que obispados y abadías pasaron a ser de nombramiento papal. Esta medida llegó al extremo con Benedicto XIII de Aviñón, el "papa Luna", quien, como primera medida de su pontificado, decretaría en 1394 que todos los beneficios de la Iglesia pasaban a ser de su propia disposición ${ }^{19}$.

Ya durante el pontificado de Clemente V numerosos obispados ibéricos fueron provistos directamente por la Santa Sede, como veremos más

\footnotetext{
${ }^{16}$ Domínguez 2014.

${ }^{17} C f$. Díaz 2010, pp. 63 y ss.

${ }^{18}$ Lo cual era relativamente frecuente dado el ansia de numerosos clérigos por estar cerca del poder papal. $C f$. Domínguez 2007.

${ }^{19} C f$. el excelente estudio de Theis 2006, pp. 169 y ss., sobre la reforma contable de la Cámara en este momento.
} 
adelante, por lo que, en consecuencia, los cabildos catedralicios se vieron privados de su derecho de elección. Pero también este papa, así como sus sucesores, lograron imponer como canónigos o beneficiados catedralicios a clérigos de su entorno, en contra de las normas de nombramiento de los mismos por parte de los propios cabildos o por los obispos.

Por otro lado, y muy relacionado con este asunto, debe tenerse en cuenta que Clemente V, y más aún sus sucesores, estuvieron muy necesitados de recursos económicos, que trataron de conseguir, y realmente consiguieron, con numerosas tasas y exacciones fiscales. Los ingresos eran absolutamente imprescindibles para mantener la complicada maquinaria burocrática de la curia, especialmente para sostener a su personal, a la vez que para sufragar los gastos enormes de la propia corte papal y del colegio de cardenales. A ello se sumarán poco más tarde los ingentes gastos ocasionados por la construcción del palacio pontificio de Aviñón ${ }^{20}$.

Las arcas de la cámara pontificia, como decimos, estaban exhaustas. Los propios diplomas papales no tienen reparo alguno en mencionarlo. Así, en 1309 Clemente V comunicaba al rey Jaime II de Aragón que no podía acceder a su petición de subsidio para sus gastos en la conquista de Granada ${ }^{21}$, diciéndole que la razón residía en la extrema ruina de las arcas papales, por estar empeñada la Sede Romana en diversos asuntos, tales como la lucha contra Venecia o la preparación de la Cruzada:

Clemens episcopus, servus servorum Dei, carissimo in Christo filio Iacobo, regi Aragonum illustri, salutem et apostolicam benedictionem (...). A nobis igitur eis audientia benigne concessa, predicti nuntii pecuniarum subsidium exhibendum tibi de nostra Camera in prosecutione negotii regni Granate, quod laudabiliter assumpsisti, inter cetera cum instantia postularunt, ad quod eis, sicut alias primis tuis nuntiis propter hoc ad nostram presentiam destinatis, duximus respondendum, videlicet, quod propter multa profluvia expensarum quas pro defensione terrarum Ecclesie quas Venetorum nephanda temeritas iam pro magna parte occupauerat violenter, necnon et passagio quod per dilectos filios magistrum et fratres Hospitalis Sancti Iohannis Ierosolimitani, feceramus, in subsidio Terre Sancte, ad preparationem passagii generalis ad quos nostra suspirat intentio, defensione quoque regni Cipri et aliarum terrarum quas adhuc tenent in partibus illis fidei predicte cultores, et ne perversi christiani, sicut usque nunc fecerant, deferrent arma et victualia sarracenis et predictis imimicis fidei impugnandis, adeo Camere nostre erat exaustum erarium, quod de huiusmodi subsidio quod tibi, sicut

${ }^{20}$ En época de los sucesores de Clemente V, concretamente bajo los pontificados de Juan XXII (1316-1334), Benedicto XII (1334-1342) y Clemente VI (1342-1352). Fue construido sobre un antiguo palacio episcopal, al borde del río Ródano, en un promontorio rocoso natural.

${ }^{21}$ Domínguez 2014, doc. 557, dado el 4-XI-1309. 
nouit Ille qui nichil ignorat, exhiberemus liberaliter et libenter non poteramus aliquatenus subvenire.

Los ingresos pontificios eran de dos tipos: los que provenían de los Estados de la Iglesia y los que se recaudaban en territorios foráneos. Los primeros habían sido tradicionalmente los de más peso, pero en este momento eran casi nulos, puesto que los Estados pontificios estaban en un absoluto estado de anarquía.

El gobierno de los Estados de la Iglesia fue confiado por Clemente $\mathrm{V}$ a una comisión de tres cardenales, mientras que en Spoleto su propio hermano, Arnaud Garsias de $\mathrm{Got}^{22}$, ocupaba el puesto de vicario papal. La confusión y la anarquía eran frecuentes, debido al odio mutuo entre los Colonna y los Orsini, a la tradicional turbulencia de los romanos ${ }^{23}$ y a los conflictos airados y frecuentes entre el pueblo y los nobles, condiciones que habían venido empeorando a través del siglo XIII y que en aquella centuria habían conducido a los papas italianos a fortalezas alejadas de dicha ciudad, tales como Viterbo, Anagni, Orvieto o Perugia ${ }^{24}$. La defensa de los Estados consumía muchos más recursos que los que se recaudaban en ellos ${ }^{25}$.

En fin, esta situación de caos en Italia propició un aumento de la recaudación pontificia en los demás lugares de la Cristiandad.

La hacienda pontificia aviñonesa fue definitivamente instituida por Juan XXII ${ }^{26}$, el sucesor de Clemente V. Sin embargo, debe reconocerse que aquel no hizo más que perfeccionar y dar carta de naturaleza a unas prácticas que comenzó a establecer su antecesor: se multiplicaron las tasas por las innumerables gracias y dispensas solicitadas al papa, se renovó la percepción de las décimas de cruzada sobre los beneficios eclesiásticos ${ }^{27}$, se concedieron centenares de beneficios "en expectativa" 28 , esto es, otorgándose derechos sobre vacantes beneficiales aún no existentes, pero que habrían de producirse, y

${ }^{22}$ Domínguez 2014, doc. 82.

${ }^{23}$ El 6 de mayo de 1308 se llegó a destruir la iglesia de San Juan de Letrán; pronto reconstruida, sin embargo, por los romanos, con la ayuda del papa.

${ }^{24}$ Clemente $\mathrm{V}$ atacó a Venecia, que se había apropiado injustamente de Ferrara, un feudo del Patrimonio de San Pedro. Cuando la excomunión, entredicho y una prohibición general de todas las relaciones comerciales fracasaron, él proscribió a los venecianos, y provocó que se predicara una cruzada contra ellos; finalmente su legado, el cardenal Pélagrue, derrotó en una dura batalla a los venecianos. $C f$. Domínguez 2014, docs. 425, 491, 493, 538, 744, 911, 1099.

${ }^{25}$ Es bien sabido que hasta la época del cardenal Gil de Albornoz, medio siglo más tarde, no se logró la pacificación, sumisión y organización de estos Estados.

${ }^{26} C f$. el libro clásico de Göller 1910.

${ }^{27}$ Especialmente en los últimos años del pontificado de Clemente V. Domínguez 2014, docs. 744, 745, 985, 1030, 1039-1041, 1115, 1116, 1197-1200, 1209, 1210, 1359-1362, 1364, 1402.

${ }^{28}$ Se concedieron más gracias en expectativa que gracias en firme a lo largo del pontificado de Clemente V. 
por las que había que abonar tasas desde el primer momento. Además, los beneficiarios de las gracias en expectativa debían abonar también una cantidad a los comisionados pontificios que, en estos casos, siempre se nombraban para que tal concesión de merced tuviera efecto ${ }^{29}$.

Por otro lado, se tuvo especial cuidado en recaudar el tradicional tributo llamado "servicio común" ${ }^{30}$, que pagaban los obispos y abades exentos ${ }^{31}$ antes de su confirmación y consagración ${ }^{32}$, a la cámara y al colegio de cardenales, en caso de que el obispado o monasterio en cuestión tuviese unas rentas superiores a los 100 florines de oro ${ }^{33}$.

Cuando las arcas de los prelados estaban vacías, lo que solía suceder muy frecuentemente, y estos no tenían suficiente liquidez para pagar el tributo del "servicio común", la cámara pontificia permitía, más bien recomendaba, la adquisición de préstamos por aquellos, frecuentemente otorgados por mercaderes-banqueros normalmente lombardos, "devotos" del pontífice, al menos en los primeros tiempos de este pontificado ${ }^{34}$.

Esta situación se dio muy frecuentemente entre los obispos hispanos durante el pontificado de Clemente V (1305-1314) ${ }^{35}$. Concretamente, se vieron obligados a solicitar estos créditos los ordinarios de Compostela ${ }^{36}$, Évora $^{37}$, Lamego $^{38}$, Gerona $^{39}$, León ${ }^{40}$, Lisboa $^{41}$, Oporto ${ }^{42}$, Orense ${ }^{43}$, Palencia ${ }^{44}$, Urgel ${ }^{45}$,

\footnotetext{
${ }^{29}$ Véase el clásico estudio de Mollat 1921.

${ }^{30}$ Cf. Domínguez 1997, pp. 51 y ss.

${ }^{31}$ Domínguez 2014, docs. 113, 121, 147, 160, 196, 221, 253, 428, 429, 487, 544, 593, $600,646,647,658,784,807,832,833,926,1074,1265,1349,1350,1386-1388,1412$, 1414.

${ }^{32} C f$. el exhaustivo listado de tasas abonadas desde fines del siglo XIII en Hoberg 1969.

${ }^{33} \mathrm{El}$ tributo correspondía a un tercio de lo que se consideraba que anualmente rentaba el beneficio. El importe de la tasa lo establecían los colectores pontificios teniendo en cuenta los ingresos medios del beneficio cada año, deduciendo del mismo las cargas que tenía.

${ }^{34}$ Domínguez 2014, docs. 50, 66, 67, 1117, 1389.

${ }^{35}$ Para contextualizar esta situación de la Iglesia hispana, véase el extraordinario artículo de Ladero (2001, pp. 121 y ss.). Cf. también Mitre 2003.

${ }^{36}$ Domínguez 2014, docs. 50,150.

${ }^{37}$ Ibidem, docs. 1223, 1315.

${ }^{38}$ Ibidem, doc. 831.

${ }^{39}$ Ibidem, doc. 1113.

${ }^{40}$ Ibidem, doc. 963.

${ }^{41}$ Ibidem, docs. 1358, 1389.

${ }^{42}$ Ibidem, doc. 657.

${ }^{43}$ Ibidem, docs. 1363, 1365, 1406.

${ }^{44}$ Ibidem, docs. 214, 222, 1259.

${ }^{45}$ Ibidem, doc. 580.
} 
Salamanca ${ }^{46}$, Toledo ${ }^{47}$, Zamora $^{48}$ y Zaragoza ${ }^{49}$, así como los abades exentos de Montearagón ${ }^{50} \mathrm{y}$ de Ripoll ${ }^{51}$. Algunos de ellos, además, no pudieron solventar el pago en el momento estipulado, por lo que incurrieron en graves sanciones. Así, en 1314 consta que el obispo de Zamora, don Diego Fernández, debía nada menos que 4.000 florines de oro a la cámara pontificia ${ }^{52}$, motivo por el cual Clemente $\mathrm{V}$ hizo todo tipo de gestiones para que dicha deuda fuera saldada.

\section{LA COLACIÓN DIRECTA DE BENEFICIOS POR EL PAPADO Y LA OPOSICIÓN EPISCOPAL}

A todo este cúmulo de despropósitos financieros hay que añadir una práctica que se extendió rápidamente en este momento, a la que queremos dedicar una atención especial: la concesión directa por parte del pontificado de beneficios y rentas en iglesias de diócesis de toda la Cristiandad, en contra de los legítimos derechos e intereses de obispos y cabildos ${ }^{53}$.

En primer lugar, se debe decir que esta práctica más o menos irregular, si no desde el punto de vista jurídico sí desde el estético y el ético, dio lugar desde un primer momento a la acumulación de beneficios eclesiásticos en manos de una sola persona. Las iglesias hispanas fueron llenándose paulatinamente, durante el papado de Clemente $\mathrm{V}$, de numerosos clérigos franceses, especialmente del sur de Francia ${ }^{54}$, que trabajaban en la curia y que jamás acudían a los lugares donde residían sus canonjías o curatos ${ }^{55}$, ni siquiera a tomar posesión de los mismos, ya que lo hacían mediante procurador.

Las tradicionales prohibiciones del Derecho canónico en contra de la multiplicidad de beneficios eclesiásticos ${ }^{56}$ quedaban anuladas con las nume-

${ }^{46}$ Ibidem, doc. 923.

${ }^{47}$ Ibidem, doc. 792.

${ }^{48}$ Ibidem, docs. 834, 1211, 1404, 1405.

${ }^{49}$ Ibidem, doc. 934.

${ }^{50}$ Ibidem, doc. 260.

${ }^{51}$ Ibidem, doc. 778.

${ }^{52}$ Ibidem, doc. 1404, dado el 4-II-1314.

${ }^{53}$ Cf. Díaz 2010, pp. 63 y ss.

${ }^{54}$ Cf. Bernard 1949, pp. 369-411.

${ }^{55}$ Cf. Hayez 2007, pp. 427-433.

${ }^{56}$ Esta práctica ya se había prohibido desde épocas antiquísimas, nada menos que en el Concilio general de Calcedonia del año 451 y en el II de Nicea del año 787. Sucesivos decretos papales y conciliares habían reiterado tal veto pero, a lo que se ve, sin gran éxito. 
rosísimas dispensas pontificias ${ }^{57}$ dadas al efecto ${ }^{58}$. Con ello los personajes curiales tuvieron enormes ingresos, pero la "cura" verdadera de las iglesias particulares, delegada en clérigos "de segunda fila", se vio seriamente afectada ${ }^{59}$.

La concesión de beneficios y prebendas en iglesia de los reinos de la Península Ibérica, durante el pontificado de Clemente $\mathrm{V}$ a clérigos franceses se atestigua al menos en medio centenar de $\operatorname{casos}^{60}$. Tales clérigos francos "recomendados" del papa fueron colocados en las catedrales de Burgos, Palma de Mallorca, Huesca, Toledo, Santiago de Compostela, Urgel, Tarragona, Zaragoza, Pamplona, Tarazona, Elna, Lérida, Calahorra, Salamanca, Jaca, Palencia, Cartagena, Barcelona y Gerona ${ }^{61}$; como vemos, prácticamente en todas las importantes iglesias hispanas.

Otras veces se puede observar que el clérigo beneficiario de una renta eclesiástica es un hispano, pero los diplomas especifican que es "familiar" de un cardenal francés, o bien que, como el arzobispo de Toledo, don Gonzalo Díaz Palomeque, estaba trabajando para la curia pontificia, tal como se expresa en un diploma del año $1308^{62}$, que dice textualmente:

Clemens episcopus, servus servorum Dei, venerabili fratri... archiepiscopo Tholetano, salutem et apostolicam benedictionem (...). Volumus insuper et mandamus quod te, in remotis agente, dilecti filii... vicarius in spiritualibus vel... officialis tui predicta omnia et singula cum diligentia exequantur.

$\mathrm{Y}$ es que, incluso en el pontificado de Clemente $\mathrm{V}$, es frecuente que las litterae gratiosae de concesión de beneficios, que obligatoriamente debían ir precedidas de una súplica oficial requiriendo dicho otorgamiento, se despachasen sin previa petición, directamente por la Cancillería, cuando iban dirigidas a clérigos conocidos de la curia. Así, en 1313, Clemente V concedía

${ }^{57}$ Cf. Bernardi 2015, pp. 197 y ss.

${ }^{58}$ Domínguez 2014, docs. 56, 59, 114, 146, 163, 180, 184, 186, 190, 192, 195, 227, 246, 247, 256, 266, 279, 284-286, 289, 299, 314, 331, 366, 378, 415, 417, 421, 422, 430, 455, 459, $461,462,465,467,469,484,512,533,534,539,542,551,556,562,570,572,573,578,594$, $601,624,635,645,666,670,672,682,684,689,694,701,709,715,733,747,760,763,765$, $775,835,841,842,844-848,851-859,861-864,867-874,879,885-888,890-895,898-902$, 904, 905, 915, 917, 924, 944, 960, 999, 1003, 1007, 1008, 1009, 1013, 1017, 1042, 1044, 1058, $1062,1063,1072,1084,1098,1100,1101,1104,1120,1121,1124-1127,1187,1194,1204$, $1236,1240,1242,1244,1246,1248,1251,1253,1255,1258,1262-1264,1271,1296,1298$, $1302,1303,1307,1321,1369,1376,1382,1399,1403,1416,1418$.

${ }^{59}$ Benito 1896, cap. 18.

${ }^{60}$ Domínguez 2014, docs. 7, 10, 31, 62, 82, 118, 141, 142, 144, 162, 188, 294, 302, 321, $365,369,371,381,395,401,411,415,484,511,560,672,677,678,682,684,709,747,760$, $763,765,835,859,903,910,935,999,1009,1022,1045,1055,1202,1204,1240,1242,1311$.

${ }^{61}$ Las especificamos por orden cronológico.

${ }^{62}$ Domínguez 2014, doc. 254, dado el 21-I-1308. 
al clérigo francés Berald de Serres una canonjía y un arcedianato en la catedral de Toledo ${ }^{63}$, diciendo lo siguiente:

Clemens episcopus, servus servorum Dei, dilecto filio Beraldo de Serris, canonico et archidiacono Godalfayarensi in ecclesia Toletana, salutem et apostolicam benedictionem. Ut tua et tuorum devotio eo amplius erga nos et Romanam crescat Ecclesiam, quo maiorem a nobis te noveris gratiam assecutum, personam tuam munificentia Sedis Apostolice providimus honorandam. Cum itaque canonicatus et prebenda et archidiaconatus Godalfayarensis in ecclesia Toletana, (...) nos, volentes tibi, premissorum consideratione, gratiam facere specialem, predictos canonicatum et prebendam ac archidiaconatum, etiam si cura eidem immineat animarum, sic vacantes (...) motu proprio, non ad tuam vel alterius pro te nobis oblate petitionis instantiam, sed de nostra mera liberalitate, auctoritate tibi apostolica, conferimus et de illis etiam providemus.

Esto iba, como ya se ha dicho, en contra de los intereses de los obispos hispanos. La lucha de poder entre ambas instituciones, el pontificado y los prelados ibéricos, se saldaba casi siempre en favor de la Sede Apostólica. Los notarios de la Cancillería pontificia especificaban en la redacción de las "bulas" de nombramiento de los beneficiados que, en virtud de la máxima autoridad papal, quedaban derogadas en ese momento y para ese caso cualesquier normativas de las iglesias locales que fueran en contra de tal decisión pontificia. De hecho, el 22 de septiembre de $1305^{64}$, antes incluso de ser coronado como papa, Clemente $\mathrm{V}$ ya reservaba para el clérigo francés de estirpe noble Arnaud de Tartas la primera canonjía prebendada vacante en la catedral de Burgos, especificándose en las litterae de colación que, por decisión papal, se anulaba cualquier costumbre o reglamento de la catedral de Burgos que pudiera impedirlo. Se derogaban concretamente estas normas: la posible fijación previa de un número máximo de canónigos que no pudiera superarse, la existencia de gracias papales anteriores que impidieran dañar a otro candidato, una probable reserva pontificia para otro solicitante, la facultad del obispo o del cabildo para impedirlo, la presentación de posibles cartas papales en contra de cualquier reserva de beneficios, etc.:

non obstantibus de certo canonicorum numero et aliis quibuscumque statutis et consuetudinibus contrariis ipsius ecclesie iuramento, confirmatione apostolica vel quacumque alia ad illam partem firmitate vallatis; seu si aliqui super provisionibus sibi faciendis de canonicatibus et prebendis vel personatibus aut digni-

${ }^{63}$ Ibidem, doc. 1204, con fecha de 25-II-1313.

${ }^{64}$ Ibidem, doc. 7. 
tatibus et prestimoniis, seu aliis beneficiis ecclesiasticis, in eadem ecclesia specialiter, vel in illis partibus generaliter, apostolicas, quibus per hoc nullum volumus preiudicium generari, vel legatorum eius litteras impetrarunt, quamvis per eas ab inhibitionem, reservationem vel decretum, vel alias quomodolibet sit processum, etiam si in canonicos eiusdem ecclesie recepti, vel ut recipiantur insistant; aut si venerabili fratri nostro episcopo et dilectis filiis capitulo Burgensibus, vel quibusvis aliis, communiter vel divisim, et prestimoniis, ab eadem Sede indultum existat quod ad receptionem vel provisionem alicuius minime teneantur, et ad id compelli, aut quod interdici, suspendi vel excommunicari non possint, seu quod de prebendis et prestimoniis ipsius ecclesie ac beneficiis ad eorum collationem spectantibus nequeat alicui provideri per litteras apostolicas non facientes plenam et expressam, ac de indulto huiusmodi mentionem, sive qualibet alia dicte Sedis indulgentia, generali vel speciali, cuiuscumque tenoris existat, per quam presentibus non expressam vel totaliter non insertam effectus huiusmodi gratie impediri valeat vel differri.

A la vez que aumentaba el enojo de los obispos hispanos, crecían también las ansias de algunos clérigos hispanos de "medrar" por todos los medios en su carrera eclesiástica al amparo del pontificado y no de sus prelados. Para ello solicitaban al pontífice la reserva de nuevos beneficios eclesiásticos, incluso a veces recurriendo a la intercesión de reyes, nobles u otras autoridades conocidas del papa. De hecho, en la documentación de este pontífice se recogen unos dos centenares de concesiones de este tipo ${ }^{65}$.

Un ejemplo extremo de concesión múltiple de beneficios eclesiásticos a una única persona es el de Juan de Aragón y Anjou, hijo de Jaime II de Aragón: en junio de 1311, Clemente $\mathrm{V}$ concedió al citado infante aragonés, que entonces contaba tan sólo con nueve años de edad, canonjías prebendadas y dignidades en las doce catedrales siguientes: Toledo, Cuenca, Burgos, Compostela, Lisboa, Palencia, Braga, León, Sevilla, Salamanca, Lérida y Valencia. Además, el día siguiente, 25 de junio de 1311, el papa le facultó para recibir otros seis beneficios eclesiásticos curados, que podrían ser personados ${ }^{66}$. Es verdad que se trataba de

${ }^{65}$ Ibidem, docs. 1-3, 5, 9, 16, 25, 26, 29, 30, 32-34, 52, 54, 57, 58, 61, 64, 70, 78, 79, 85, 90, 91, $93,98,99,114,130,132,153,159,169,171,173,178,182,183,192,194,233,246,247-249$, $256,266,271,280,284,288,289,296,299,309,312,314,317,323,327,329,331,375,384$, $388,403,407,409,410,421,430,455,465,467,469,479-481,496,539,541,542,549,554$, $556,570,572,573,578,583,594,603,624,629,635,638,642,645,664-666,670,679,694,701$, $703,715,724,725,733,736,755,830,841,842,844-848,851-856,861-864,867-874,885-888$, 890-895, 898-902, 912, 914, 915, 917, 924, 932, 984, 1003-1005, 1007, 1012, 1013, 1016, 1017, $1023,1042,1046,1048,1049,1051,1056,1058,1069,1072,1075-1077,1087,1100,1181$, $1190,1192,1194,1231,1232,1236,1244,1246,1248-1251,1253,1255,1264,1272,1296$, 1298, 1302-1304, 1306, 1308, 1313, 1318, 1369, 1377-1381, 1391, 1411, 1416, 1418.

${ }^{66}$ Ibidem, docs. 841, 842, 844-848, 851-856, 861-864, 867-874, 885-888, 890-894, 898-902, 1232-1235, 1240-1247. 
un infante y que el favor hacia los hijos de los reyes era habitual desde siglos atrás por parte del papado, pero ahora la situación se lleva al límite, con el consiguiente malestar de las autoridades eclesiásticas ibéricas.

Lógicamente, tal práctica exagerada llegó a ser contraproducente. El caso más extremo de ello lo tenemos en la iglesia de Burgos ${ }^{67}$. En ella Clemente V había establecido como prebendados, entre 1305 y 1309, aproximadamente a una docena de clérigos franceses de su entorno propio, lo cual era un abuso de tal calibre que ni el obispo ni el cabildo lo pudieron soportar. La irritación llegó al extremo en 1310, cuando el papa designó otros cinco clérigos francos como canónigos burgaleses. El obispo de Burgos, don Pedro Rodríguez Quijada, se opuso brutalmente a ello. Lo mismo hicieron los canónigos hispanos de su iglesia. Cuando se presentaron en Burgos los procuradores de los cinco clérigos franceses promovidos por el papa, para tomar posesión de sus canonjías prebendadas, llovieron insultos y "garrotazos" contra ellos. Según afirma textualmente el mandato pontificio, cuando llegó a Burgos el primero de los procuradores citados, fue aterrorizado con graves palabras, con el consentimiento del obispo, para que se marchase de la ciudad; otro fue arrastrado por la cabellera y encerrado en las cloacas de la catedral; un tercero fue pateado y expulsado a palos; un cuarto fue amenazado de muerte; y el último tuvo que huir a uña de caballo, de vuelta desde Burgos a Francia, pero dando un rodeo de más de doce jornadas de camino por miedo a ser asesinado.

De hecho, el papa ${ }^{68}$, para tratar de resolver este dramático desaguisado, tuvo que recurrir a la máxima autoridad eclesiástica castellana, el arzobispo de Toledo ${ }^{69}$.

Esta terrible situación, aunque tuvo consecuencias canónicas penales para el obispo y el cabildo de Burgos, fue un serio aviso para el pontificado y consiguió efectos positivos. Lo sabemos con certeza porque, a partir de ese momento, mediados del año 1310, las concesiones de beneficios a clérigos franceses en iglesias ibéricas disminuyeron en gran medida y Clemente V no se atrevió a forzar más una situación que veía que, si tensaba más, no podría controlar.

Para acabar con este tema, hay que reconocer, a pesar de lo dicho, que los beneficios eclesiásticos no siempre los concedía Clemente V a sus "amigos" o cortesanos. También hay varios casos en la documentación en los que "clérigos pobres en espera de beneficio" impetraban a la Sede Romana

${ }^{67}$ Ibidem, docs. 7, 8, 31, 69, 82, 83, 114, 115, 240, 245, 331, 332, 395, 479, 515, 545-547, $551,645,664,665,672,673,693,756,757,759,803-806,835,853-856,861-864,867-874$, $885-888,890,891,898-901,1044,1117,1244-1247,1282,1406$.

${ }^{68}$ Ibidem, doc. 664, dado el 7-V-1310.

${ }^{69}$ Don Gonzalo Díaz Palomeque, en ese momento. 
y conseguían unas litterae de provisión, tal como, por ejemplo, lo expresa el siguiente diploma ${ }^{70}$ :

Clemens episcopus, servus servorum Dei, dilecto filio Petro, dicto Adressa, canonico ecclesie Sancti Iohannis de Perpiniano, Elnensis diocesis, salutem et apostolicam benedictionem. Laudabile testimonium quod tibi (...) canonicatum, prebendam et capellaniam predictos, sic vacantes, cum plenitudine Iuris canonici, ac omnibus iuribus et pertinentiis suis, apostolica tibi auctoritate conferimus (...) non obstantibus quibuscumque (...) sive quod olim super provisione tibi facienda de aliquo beneficio ecclesiastico spectante ad collationem vel presentationem dilecti filii archidiaconi Confluentis in ecclesia Elnensi, si quod in civitate vel diocesi Elnensibus tunc vacaret, vel cum ad id se facultas offerret, nostras in ea forma, in qua pro pauperibus clericis beneficiandis interdum scribere consuevimus, litteras impetrasti, ex quibus nondum fuisti beneficium aliquod assecutus.

\section{LA SUPRESIÓN DEL TEMPLE Y LA COLACIÓN POR EL PAPADO DE LAS IGLESIAS ANTERIORMENTE TEMPLARIAS. RECHAZO DE LOS OBISPOS HISPANOS}

Por otro lado, hay un asunto que claramente destaca en el papado de Clemente $\mathrm{V}$ y que, de forma más o menos directa, también tuvo que ver con la provisión de beneficios eclesiásticos directamente por parte del pontificado. Nos referimos a la polémica supresión de la orden del Temple, tema sobre el cual los estudios son casi infinitos ${ }^{71}$.

Desde la expulsión final en el año 1291 de las fuerzas cruzadas de San Juan de Acre, último reducto de las mismas en Tierra Santa, las órdenes militares en Europa habían sido objeto de una crítica adversa, en parte porque se atribuía a las rivalidades entre ellas la humillante derrota, en parte a causa de la enorme riqueza que habían adquirido en su corta existencia. Los templarios, en este sentido, eran los más poderosos y quizá los más insolentes y soberbios $^{72}$. Su tradicional carácter militar y religioso, sin embargo, había ido cediendo paso ante el financiero. En torno al cambio de la decimotercera a la

\footnotetext{
${ }^{70}$ Domínguez 2014, doc. 917, dado el 3-XI-1311.

${ }^{71}$ Nos han servido de mucha ayuda las siguientes obras, que exponemos por orden cronológico de edición: Delaville 1882; Ayneto 1904; Finke 1907; Boutaric 1910; Miret 1911; Müller 1934; Javierre 1961; Vilar 1962; Estepa 1975; Barber 1978; Barquero 1993; Martínez 1993; Frale 2006; García 2007; Nadal 2010.

${ }^{72} \mathrm{Se}$ ha calculado que en el momento de su supresión el número de caballeros templarios era de unos 4000, la mitad de ellos en Francia.
} 
decimocuarta centuria, los templarios se habían mostrado juiciosos y hábiles financieros, mucho más de fiar que los tradicionales mercaderes-prestamistas judíos o lombardos.

Desde el año 1305 Felipe IV el Hermoso de Francia comenzó a exigir a Clemente V la supresión de esta orden. El papa no dio crédito por entonces a las acusaciones formuladas contra el Temple. Felipe IV continuó durante dos años más reuniendo pruebas contra ella de forma "subterránea". Finalmente, a causa de la debilidad e irresolución de Clemente V, el plan real dio resultado. Después de un intento infructuoso del papa en agosto de 1307 para unir templarios y hospitalarios, Clemente V cedió a las exigencias del rey Felipe y ordenó una investigación sobre la orden, contra la cual el monarca presentó supuestos cargos de herejía: renuncia, blasfemia y desprecio formal de Cristo, inmoralidad, idolatría, omisión de la consagración en la celebración de la misa, etc.

El rey francés, con la ayuda de sus juristas, sin esperar la decisión definitiva de la curia pontificia, arrestó el 13 de octubre de 1307, en París, al gran maestre de los templarios, Jacques de Molay, y a numerosos caballeros, a lo que siguió una orden para apresar a todos los templarios de Francia y para retener los bienes de la orden. Mientras Felipe IV invitaba a los reyes de Europa a seguir su ejemplo, Clemente V, el 27 de octubre de 1307, protestaba contra la usurpación real de la autoridad papal, exigía transferir a su custodia los prisioneros y sus bienes, y suspendía la autoridad inquisitorial de los eclesiásticos del rey y los obispos franceses. Felipe IV se sometió en apariencia, pero presentó al papa numerosas pruebas testificales de horribles crímenes supuestamente cometidos por los templarios, obtenidas a través de torturas. Ante dichas confesiones, Clemente V publicó un decreto, el 22 de noviembre de 1307, ordenando una investigación de los cargos contra los templarios en todos los reinos europeos. En casi todos los territorios hispanos, en especial en los reinos de Mallorca, Aragón, Castilla y Portugal, las primeras indagaciones fueron favorables a la orden; y en ningún lugar se obtuvieron confesiones como las conseguidas en Francia.

La cuestión de la posible disolución de la orden fue reservada para un concilio general, convocado en Vienne ${ }^{73}$. El 22 de marzo de 1312 el papa decretó que, si bien no encontraba suficientes razones para una condenación formal de la orden, no obstante, por razones de bienestar común, del odio abrigado contra ellos por el rey de Francia, de la naturaleza escandalosa de su juicio y de la probable dilapidación de los bienes de la orden en todo el territorio cristiano, suprimía el Temple en virtud de su poder soberano de provisión apostólica, y no por ninguna sentencia condenatoria definitiva ${ }^{74}$.

\footnotetext{
${ }^{73}$ Véase el conocido y gran estudio de Müller 1934.

${ }^{74}$ Clemente $\mathrm{V}$ dejó ver en todo este proceso un carácter débil y vacilante. Parece que estaba convencido de la culpa de los templarios, especialmente después de que tantos la hubieran
} 
El 2 de mayo el papa confirió a los hospitalarios el derecho a los bienes de la orden suprimida en todos los territorios, salvo en los reinos hispánicos de Mallorca, Aragón, Castilla y Portugal, que, a través de diversas maniobras, habían retrasado la pertinente información sobre el estado de la orden en sus territorios.

Efectivamente, la postura adoptada por reyes y prelados hispanos ante las maniobras para la supresión de la orden del Temple, como se viene diciendo, fue en general muy diferente a la sostenida por los vecinos francos. Salvo en el reino de Navarra, en los demás las indagaciones fueron favorables a los templarios y, además, los pesquisidores se negaron a recurrir a métodos drásticos. De ahí que el 30 de marzo de 1311 Clemente V requiriese a los comisionados pontificios al efecto que, puesto que no habían obtenido

confesiones definitivas de los templarios hispanos sobre sus crímenes, tal como había pasado en el reino de Francia, les volviesen a interrogar, aplicándoles tortura mediante un verdugo "religioso", para obtener definitivamente la verdad ${ }^{75}$.

En efecto, en los reinos de Hispania la oposición a acatar las órdenes papales de una dura investigación contra los templarios es evidente. De hecho, el papa tuvo que ordenar repetidas veces a los inquisidores hispanos que actuaran con contundencia contra los templarios, aunque con ello no consiguió resultado alguno. Cuando se acercaba la celebración del concilio de Vienne no acababan de llegar informes especialmente negativos contra los templarios desde Hispania. Finalmente, tras dicho concilio, Clemente V dictaminaba ${ }^{76}$ :

Clemens episcopus, servus servorum Dei, dilectis filiis universis administratoribus et curatoribus ad administrandum et conservandum bona quondam Domus et Ordinis Militie Templi, apostolica et quacumque auctoritate alia deputatis, ubicumque consistentia, salutem et apostolicam benedictionem. Nuper in Generali Concilio per nos Vienne, disponente Domino, celebrato, post longam deliberationem prehabitam et maturam, acceptabilius fore credentes Altissimo magis honorabile fidei orthodosse cultoribus, ac subventioni Terre Sancte utilius extimantes, bona quondam Domus et Ordinis Militie Templi, Ordini Hospitalis Sancti Iohannis

admitido, lo que explica su recomendación del uso de la "tortura bajo mano eclesiástica", así como su tolerancia a la supresión por parte del rey de toda libertad de defensa para los acusados. De una u otra forma, sin embargo, Felipe IV consiguió finalmente apropiarse de la mayor parte de las riquezas de la orden del Temple en Francia. Los templarios que siguieron manteniendo sus confesiones fueron dejados libres; aquellos que se retractaron fueron considerados herejes reincidentes y, como tales, fueron llevados a los tribunales de la Inquisición.

${ }^{75}$ Domínguez 2014, doc. 800.

${ }^{76}$ Ibidem, doc. 980. 
Ierosolimitani concedere, quam Ordini de novo creando, unire aut etiam applicare consilium deliberationis nostre providit; sed quia tunc aliquibus asserentibus utilius fore bona ipsa Ordini noviter creando conferre, quam dicti Hospitalis Ordinis applicare, tunc noster affectus speratum effectum super hoc obtinere nequivit, tandem uero, sic per Dei gratiam actum fore dinoscitur, quod VI nonas presentis mensis maii, eodem sacro apropbante Concilio, Hospitali seu ipsius Hospitalis Ordini supradictis prefata bona concedenda et applicanda duximus et etiam unienda, bonis eiusdem Ordinis Militie Templi in regnis et terris carissimorum in Christo filiorum nostrorum... Castelle,... Aragonum,... Portugalie et... Maioricarum regum illustrium extra regnum Francie consistentibus dumtaxat exceptis, que ab unione, concessione et applicatione huiusmodi, ex certis causis, excipienda duximus et etiam excludenda, ipsa dispositioni nostre et Sedis Apostolice specialiter reservantes, quousque de illis aliter pro dicte Terre subsidio per nostram et dicte Sedis providentia extiterit ordinatum.

El papa estaba muy molesto con la actitud de las autoridades hispanas, que continuamente ponían trabas a las actuaciones pontificias sobre la orden del Temple. Poco después de finalizado el concilio de Vienne, el 23 de agosto de $1312^{77}$, Clemente V pedía a Jaime II, rey de Aragón, que antes del primer día hábil del próximo mes de febrero (concretamente, el jueves 1 de febrero de 1313), le informara sobre su parecer en torno al futuro de los bienes de la extinta orden del Temple en Aragón.

¿Qué sucedió concretamente en cada uno de los reinos hispánicos? Jaime II de Aragón, desde muy pronto, pidió su parecer al papa sobre la posible supresión de los templarios ${ }^{78}$. A pesar de las reticencias iniciales, el 1 de diciembre de 1307 el rey mandó que fueran detenidos los templarios de su reino, ante lo cual estos se hicieron fuertes en sus castillos. Poco a poco fueron cayendo todas sus fortalezas: Peñíscola, Burriana, Miravet, Monzón, Cantavieja, etc. El maestre provincial de Aragón pidió al arzobispo de Tarragona la celebración de un concilio en esa ciudad, que, en 1312, proclamaría la inocencia de los templarios, pero ya después de haber sido abolida la orden en el concilio de Vienne. El citado arzobispo, Guillem de Rocabertí, tuvo el valor suficiente para oponerse en cierta medida a Clemente V.

Sin embargo, los templarios aragoneses quedaron adscritos a sus lugares y pronto se les obligó a dispersarse por los diferentes obispados donde

\footnotetext{
${ }^{77}$ Ibidem, doc. 1109.

${ }^{78}$ Sobre la supresión de esta orden en Aragón, $c f$. ., entre otros, Ayneto 1904; Miret 1911; Sans i Travé 1991; Nadal 2010. Véase también Domínguez 2014, docs. 228, 251, 255, 341, 343, 346 , $355,359,360,363,364,390,394,396-398,400,404,518,519,527,652,769,783,794,797$, $817,818,897,908,967,980,981,1109,1229,1257,1267,1268,1273-1275$.
} 
tenían bienes, vetándoseles incluso la libre circulación por el reino ${ }^{79}$. Ya se dijo que los embajadores aragoneses asistentes al concilio de Vienne consiguieron que los bienes de la orden del Temple en Aragón no fueran entregados a la del Hospital de Jerusalén. Lo mismo hizo en mayo de 1313 el propio rey. Justificando la existencia de las órdenes militares hispánicas y su activo papel en la Reconquista, el rey de Aragón consiguió que seis años después, en 1318, se creara en el reino de Valencia una nueva orden, la de Montesa, a la que pasarían los bienes de los templarios en aquel lugar; mientras que los bienes existentes en Aragón y Cataluña pasarían a engrosar la Castellanía de Amposta o el Gran Priorato de la orden de San Juan.

En el reino de Castilla debe decirse que, desde un primer momento, Fernando IV se mostró partidario de los templarios ${ }^{80}$. Clemente V comisionó a los arzobispos de Toledo y Compostela, así como a los obispos de Palencia y Lisboa, para que investigasen los supuestos crímenes de los templarios en Castilla. En la ciudad de Salamanca se dio una sentencia definitiva sobre este asunto, en octubre de 1310, declarando por unanimidad inocentes a los templarios. De nuevo vemos a cuatro altos prelados castellanos actuando, en cierta medida, en contra del parecer papal.

Tras el concilio de Vienne y la supresión del Temple, el 23 de agosto de 1312 Clemente V pidió a Fernando IV que le expusiera su parecer sobre el futuro de los bienes de los templarios castellanos, que estaban siendo incautados por la corona. Finalmente, el 14 de marzo de 1319 Juan XXII decretó la entrega de los bienes templarios de Castilla a la orden del Hospital de Jerusalén ${ }^{81}$. Sin embargo, muchas posesiones del Temple ya estaban en manos de la corona castellana, y otras fueron a parar a manos de la alta nobleza y de las órdenes de Alcántara y Santiago, aunque algunas, en efecto, pasaron a manos de la orden del Hospital ${ }^{82}$.

Dinís I de Portugal también fue favorable a la causa templaria ${ }^{83}$. De modo similar a lo que había sucedido en Aragón, el rey Dinís I consiguió que, años después, en 1319, los bienes de los templarios se adscribieran a una nueva orden religiosa, la llamada orden de Cristo.

\footnotetext{
${ }^{79}$ Hasta que, en el año 1331, Juan XXII les permitió ingresar en otras órdenes.

${ }^{80}$ En torno a la supresión del Temple en Castilla, $c f$., entre otros, Javierre 1961; Estepa 1975; Barquero 1993; Martínez 1993. Véase también Domínguez 2014, docs. 341, 345, 347, 349, $350,352-354,356,362-364,390,392,548,553,652$, 769, 793, 799, 800, 897, 967, 980, 981, $1110,1273-1275$.

${ }^{81} C f$. Archivo Histórico Nacional, Órdenes Militares, San Juan de Jerusalén, carp. 569, n. ${ }^{\circ} 31$.

${ }^{82}$ Muchos templarios ingresaron en la orden de Calatrava.

${ }^{83}$ Sobre la supresión de la orden del Temple en Portugal, $c f$. Domínguez 2014, docs. 341, $345,347,349,350,352-354,356,362-364,390,392,548,553,652,769,793,799,800,897$, $967,980,981,1110,1273-1275$.
} 
Jaime II y Sancho I de Mallorca en un principio tampoco fueron proclives a la supresión de la orden ${ }^{84}$. El obispo de Mallorca, don Guillem de Vilanova, fue comisionado por el papa el 15 de marzo de 1313 para absolver o condenar a freiles templarios de su diócesis, de acuerdo con lo aprobado en el concilio de Vienne. El papa escribió en diversas ocasiones al monarca, rogándole que le expresara claramente su parecer sobre los bienes de los templarios. De nuevo vemos una alianza monarca-obispo en este reino, enfrentados ambos al pontificado. Ante la negativa reiterada de Sancho I a responder, el 11 de julio de 1313 el papa dictaminó que se incorporasen a la orden de San Juan los bienes de los templarios sitos en el reino de Mallorca. Sin embargo, de forma sorprendente, al día siguiente, 12 de julio, Clemente V se retractó de esta decisión, y un día más tarde, el 13 de julio, se los donó al rey Sancho I.

Como se dijo, la situación fue distinta en Navarra ${ }^{85}$, donde el monarca Luis I Hutin, coronado en 1307, hijo de Felipe IV de Francia, se mostró absolutamente partidario de las tesis del monarca francés, su padre. Los bienes de los templarios fueron allí incautados rápidamente y los caballeros localizados en el reino, fuesen o no navarros, apresados. Clemente $V$ encargó dicha incautación al obispo de Pamplona (Arnaldo de Puyana), al prior de Roncesvalles y al deán de Tudela, el 2 de mayo de 1312.

Tras la supresión de la orden del Temple, el pontificado consiguió otra nueva fuente de beneficios en los reinos de la Cristiandad, entregando a clérigos seculares la cura de las iglesias que habían sido tradicionalmente de la misma o bien de presentación de sus dignatarios. Pero también fue una nueva fuente de conflictos y de luchas de poder entre el papado y los obispos locales. Evidentemente, se puede comprender la indignación que produjo en los obispos hispanos la designación directa de numerosos clérigos para ocupar iglesias antes templarias. Tales nombramientos se hicieron en ocasiones sin tener en cuenta la autoridad ordinaria de los obispos sobre las iglesias de su diócesis. En las cartas papales de colación de dichas iglesias, la Cancillería papal recurría a una norma que afirmaba que tales beneficios que habían sido de presentación del Temple quedaban reservados para el papa, aunque se supiera que la "institución" del clérigo perteneciera antiguamente al obispo diocesano. La gran mayoría de los diplomas lo expresa casi siempre con estas palabras:

${ }^{84}$ Por lo que respecta a la desaparición de la orden del Temple en el reino de Mallorca, $c f$. García 2007. Véase también Domínguez 2014, docs. 341, 357, 363, 390, 514, 518, 783, 967, 980, 981, 1112, 1207, 1267, 1268, 1270, 1273-1275, 1293, 1294, 1316.

${ }^{85}$ Sobre la supresión de esta orden en Navarra, cf. Domínguez 2014, docs. 341, 363, 390, $391,518,783,967,982$. 
Probitatis merita tue, super quibus laudabile tibi perhibetur testimonium, nos inducunt ut personam tuam specialis prerogativa favoris et gratie prosequamur. Cum itaque parrochialis ecclesia de (...) Ilerdensis diocesis, cuius fructus, redditus et prouentus sexaginta librarum Turonensium parvorum, secundum taxationem decime, valorem annuum, ut asseris, non excedunt, olim ad quondam Ordinem Militie Templi Ierosolimitani, tempore quo in Generali Concilio Viennensi per nos pridem, disponente Domino, celebrato, predictum Ordinem, certis et rationabilibus causis, subtulimus, cassavimus et perpetue prohibitioni subiecimus, pleno iure pertinens, quamvis illi per perpetuum vicarium, presbiterum secularem, ad presentationem fratrum dicti Ordinis per loci ordinarium institutum ibidem, consueverit deserviri, per huiusmodi sublationem, cassationem et prohibitionem vacare dicatur ad presens, de qua nullus preter nos disponere potest, pro eo quod nos tempore sublationis, cassationis et prohibitionis predictarum omnia bona tunc ad Ordinem ipsum spectantia in illis partibus consistentia dispositioni nostre et Sedi Apostolice duximus reservanda.

Los archivos pontificios nos han dejado clara constancia de esta situación en los diversos territorios hispanos, fundamentalmente en los reinos orientales de la Península. Véanse las siguientes iglesias aragonesas y mallorquinas de la orden del Temple que el Papa concedió a clérigos seculares, sin contar para ello con la aquiescencia del obispo del lugar: Ademuz (prov. de Valencia, diócesis de Segorbe-Albarracín) ${ }^{86}$, Albentosa (Teruel, diócesis de Zaragoza ${ }^{87}$, Alfambra (Teruel, diócesis de Zaragoza) ${ }^{88}$, Ambel (Zaragoza, diócesis de Tarazona ${ }^{89}$, Ballobar (Huesca, diócesis de Lérida $)^{90}$, Bellver de Cerdanya (Lérida) ${ }^{91}$, Calvera (Huesca, diócesis de Lérida) ${ }^{92}$, Camañas (Teruel, diócesis de Zaragoza) ${ }^{93}$, Cantavieja (Teruel, diócesis de Zaragoza) ${ }^{94}$, La Cañada de Benatanduz (Teruel, diócesis de Zaragoza) ${ }^{95}$, Celadas (Teruel, diócesis de Zaragoza ${ }^{96}$, Cofita (Huesca, diócesis de Lérida) ${ }^{97}$, Corbins (Lérida) ${ }^{98}$, La

\footnotetext{
${ }^{86}$ Ibidem, docs. 1146-1147.

${ }^{87}$ Ibidem, docs. 1156-1157.

${ }^{88}$ Ibidem, docs. 1150-1151.

${ }^{89}$ Ibidem, docs. 1178-1179.

${ }^{90}$ Ibidem, docs. 1122-1123.

${ }^{91}$ Ibidem, docs. 1158-1159.

${ }^{92}$ Ibidem, docs. 1132-1133.

${ }^{93}$ Ibidem, docs. 1166-1167.

${ }^{94}$ Ibidem, docs. 1027, 1413.

${ }^{95}$ Ibidem, docs. 1168-1169.

${ }^{96}$ Ibidem, docs. 1138-1139.

${ }^{97}$ Ibidem, docs. 1130-1131.

${ }^{98}$ Ibidem, docs. 1172-1173.
} 
Cuba (Teruel, diócesis de Zaragoza) ${ }^{99}$, Encinacorba (Zaragoza) ${ }^{100}$, Gardeny (Lérida) ${ }^{101}$, Graugés (Barcelona, diócesis de Vic) ${ }^{102}$, La Iglesuela del Cid (Teruel, diócesis de Zaragoza) ${ }^{103}$, Mirambel (Teruel, diócesis de Zaragoza) ${ }^{104}$, Miravet (Tarragona, diócesis de Tortosa) ${ }^{105}$, Montsonís (Lérida) ${ }^{106}$, Ontiñena (Huesca, diócesis de Lérida) ${ }^{107}$, Orrios (Teruel, diócesis de Zaragoza) ${ }^{108}$, Perales de Alfambra (Teruel, diócesis de Zaragoza) ${ }^{109}$, Pollença (Mallorca) ${ }^{110}$, Selma (Tarragona, diócesis de Barcelona) ${ }^{111}$, Tronchón (Teruel, diócesis de Zaragoza) ${ }^{112}$, Villarluengo (Teruel, diócesis de Zaragoza) ${ }^{113}$ y Villel (Teruel, diócesis de Zaragoza) $)^{114}$.

\section{A MODO DE CONCLUSIÓN}

En fin, concluimos aludiendo a que todo este ingenioso y sutil sistema recaudatorio y de designación directa de beneficiados en catedrales, colegiatas y antiguas iglesias templarias, diseñado en los comienzos del pontificado de Aviñón, logró mejorar los ingresos de la curia y "colocar" a numerosos eclesiásticos curiales, pero dañó enormemente el prestigio de la Iglesia. Tales prácticas continuaron durante todo el período aviñonés. El papado, como consecuencia de ello, aparecía ante toda la Cristiandad como un ente receptor de tributos de terrible voracidad y como una insaciable máquina para "situar" convenientemente a los cientos de clérigos francos que pululaban en el entorno de la corte de Aviñón ${ }^{115}$.

\footnotetext{
${ }^{99}$ Ibidem, docs. 1174-1175.

${ }^{100}$ Ibidem, docs. 1160-1161.

${ }^{101}$ Ibidem, docs. 1176-1177.

${ }^{102}$ Ibidem, docs. 1162-1163.

${ }^{103}$ Ibidem, docs. 1154-1155.

${ }^{104}$ Ibidem, docs. 1136-1137.

${ }^{105}$ Ibidem, docs. 1170-1171.

${ }^{106}$ Ibidem, docs. 1128-1129.

${ }^{107}$ Ibidem, docs. 1025, 1026, 1413.

108 Ibidem, docs. 1148-1149.

109 Ibidem, docs. 1144-1145.

${ }^{110}$ Ibidem, docs. 1152-1153.

${ }^{111}$ Ibidem, docs. 1142-1143.

112 Ibidem, docs. 1134-1135.

${ }^{113}$ Ibidem, docs. $1118-1119$.

${ }^{114}$ Ibidem, docs. 1140-1141.
}

${ }^{115}$ A pesar de todo lo dicho hasta ahora, también hay que reconocer la labor social desarrollada en el pontificado de Clemente V. De hecho, en numerosas ocasiones este papa favoreció la labor de los hospitales hispanos dedicados a acoger a pobres y peregrinos (Ibidem, docs. 51, $270,385,576,577,865,866,932,940,953,967,1120)$. Del mismo modo, amparó las leproserías 
Creemos haber sabido dar una corta pero clara muestra de esta nueva postura del pontificado, que reservaba y/o concedía de forma directa numerosos beneficios en todo el orbe cristiano, incluido el hispano, de espaldas a los obispos e incluso en contra de su voluntad. Cientos de nuevos racioneros francos ocuparon canonjías hispanas y dilapidaron sus rentas. Otros clérigos cercanos al papado, como los de sangre regia, accedieron, en contra de las normas del Derecho canónico, a múltiples beneficios. Ya dijimos que el clérigo e infante Juan de Aragón reunió por entonces dieciocho canonjías con tan solo nueve años. Y, como acabamos de relatar, numerosísimas iglesias que habían sido de presentación de la orden del Temple ahora son ocupadas por clérigos nombrados directamente por el papa, sin contar con el favor episcopal.

Por otro lado, la exigencia de subsidios fue continua. Se multiplicaron las tasas por las innumerables gracias y dispensas solicitadas al papa. Se renovó la percepción de las décimas de cruzada sobre los beneficios eclesiásticos $^{116}$. Se concedieron centenares de beneficios "en expectativa", esto es, sobre vacantes beneficiales aún no existentes y por las que había que abonar tasas desde el principio. El pontificado tuvo especial cuidado en recaudar el tradicional tributo llamado "servicio común". Además, se facilitó la adquisición de préstamos para poder solventar tales tributos, porque las arcas episcopales estaban aún más exhaustas que la papal.

Todo ello hizo que el ascendiente del pontificado fuera degradándose paulatinamente, tanto durante el pontificado de Clemente V como en el de sus sucesores, y se difundió en muchas partes de Europa un clima de abierta hostilidad hacia el mismo y en contra de la misma autoridad de los pontífices romanos. En algunos lugares, como Inglaterra, se alzaron especialmente las voces contra este sistema de reserva de beneficios y de aumento de tasas. Allí se consiguió el efecto contrario al deseado por los papas: desde la época de Clemente $\mathrm{V}$ se pusieron todo tipo de trabas a las actuaciones del pontificado, lo cual se acentuó algo más tarde: diversas leyes y estatutos, proclamados oficialmente desde el año 1351, dejaron en manos de los reyes la provisión de los beneficios eclesiásticos. Asimismo, se sancionó con penas terribles de cárcel perpetua y confiscación de bienes a quienes apelasen a los tribunales pontificios contra las sentencias dictadas por los tribunales ingleses. Incluso se prohibió la aceptación de las bulas papales y el envío de sumas de dinero a la Iglesia ${ }^{117}$.

que, por entonces, aún estaban extendidas a lo ancho de la Península Ibérica (Ibidem, docs. 714, 739), o promovió la redención de cautivos cristianos en manos de los musulmanes (Ibidem, doc. 235).

${ }^{116} C f$. Farelo 2013, pp. 55 y ss.

${ }^{117}$ Todo ello fue el germen de una Iglesia anglicana sometida al rey. 
Además, en este momento, en Europa se dio otra circunstancia: la recepción del Derecho romano contribuyó claramente a fortalecer en el plano teórico el poder real. Los juristas al servicio de los reyes, entre los que destacaban los de Felipe IV el Hermoso, que ya habían mantenido diversas luchas con Bonifacio VIII, tuvieron un papel relevante en esta evolución hacia las modernas monarquías nacionales. Esos juristas no querían conseguir un estado neutro religiosamente o aconfesional (es más, consideraban como el fin principal del Estado la defensa de la religión); sin embargo, rechazaban el absolutismo teocrático al que antes nos hemos referido, y proclamaban la independencia total del poder real con relación al pontificado. Como también afirma el profesor Orlandis ${ }^{118}$,

esta secularización del Estado cerraba el paso a cualquier intervención de los papas que supusiera mengua de la autoridad soberana; pero, al mismo tiempo, la omnipotencia del poder real se extendía también a los asuntos eclesiásticos y favorecía la configuración de Iglesias nacionales en los distintos reinos,

entre las que cabe destacar la inglesa y también la francesa ${ }^{119}$.

Desde inicios del siglo XIV las luchas de poder entre el pontificado y los obispos fueron uno más de los síntomas de un claro declive de la institución papal, y pueden también considerarse uno de los múltiples gérmenes que, con el tiempo, desembocarían en la Reforma protestante.

\section{BIBLIOGRAFÍA CITADA}

Ayneto Balldellou, Juan (1904), Historia de los templarios de Aragón y Cataluña, Lérida, Imprenta Mariana.

Bambauer, August (1920), Philipp der Schöne und Bonifaz VIII in ihrer Stellung zur französischen Hirche, Friburgo, Albert-Ludwigs-Universität zu Freiburg.

Barber, Malcolm (1978), The Trial of the Templars, Cambridge, University Press.

Barquero Goñi, Carlos (1993), El conflicto por los bienes templarios en Castilla y la orden de San Juan, "En la España Medieval" 16, pp. 37-54. Benito Golmayo, Pedro (1896), Instituciones del Derecho canónico, Madrid, Librería de Gabriel Sánchez.

\footnotetext{
${ }^{118}$ Orlandis 1989, p. 373.

${ }^{119}$ Lo cual prácticamente no se alteró hasta la Edad Contemporánea.
} 
Berger, Élie (1910), Bulle de Clément V en faveur de Guillaume de Nogaret, en Mélanges offerts à M. Émile Châtelain, París, reimpr. Forgotten Books, pp. 268-270.

Bernard, Jacques (1949), Le népotisme de Clément $V$ et ses complaisances pour la Gascogne, "Annales du Midi” 6/1, pp. 369-411.

Bernardi, Phlippe (2015), L'enregistrement des dépenses pontificales à Avignon au XIV siècle. Quelques réflexions sur les sources des Grands Livres et sur le rôle de cursores, en Classer, dire, compter. Discipline $d u$ chiffre et fabrique d'une norme comptable, París, Institut de la Gestion Publique et du Développement Économique, pp. 179-198.

Boutaric, Edgar (1910), Clément V, Philippe le Bel et les templiers, París, Victor Palmé.

Curley, Mary Mildred (1927), The Conflict between Pope Boniface VIII and King Philip IV the Fair, Washington, The Catholic University of America.

Delaville Le Roulx, Joseph (1882), Documents concernant les templiers extraits des archives de Malte, París, Plon.

Díaz Ibáñez, Jorge (2010), La provisión pontificia de beneficios eclesiásticos en el reino de Castilla durante el periodo aviñonés. Estado de la investigación, "Lusitania Sacra: Revista do Centro de Estudos de Historia Eclesiastica" 22, pp. 63-84.

Domínguez Sánchez, Santiago (1997), Aproximación a los documentos fiscales de la Cámara pontificia: dos litterae conservadas en el Archivo de la Catedral de León, "Estudios Humanísticos. Geografía, Historia y Arte" 19, pp. 51-66.

Domínguez Sánchez, Santiago (2006), Documentos de Bonifacio VIII (12941303) referentes a España, León, Universidad de León.

Domínguez Sánchez, Santiago (2007), Los procuradores de los reinos hispanos ante la curia romana en el siglo XIII, León, Universidad de León.

Domínguez Sánchez, Santiago (2014), Documentos de Clemente V (13051314) referentes a España, León, Universidad de León.

Ehrle, Franz (1888), Der Nachlaß Clemens' V. und der in Betreff desselben von Johann XXII. (1318-1321) geführte Process, en Archiv für Literatur und Kirchengeschichte des Mittelalters, vol. IV, Berlín, Weidmannsche Buchhandlung, pp. 1-158.

Estepa Díez, Carlos (1975), La disolución de la orden del Temple en Castilla y León, "Cuadernos de Historia. Anexos de la revista Hispania" 6, pp. 121-186.

Farelo, Mário (2013), Payer au roi et au pape. Les décimes pontificales imposées au clergé portugais pendant l'époque avignonnaise, en Morelló Baget, Jordi (ed.), Financiar el reino terrenal. La contrucción de la 
Iglesia a finales de la Edad Media (s. XIII-XVI), Barcelona, CSIC Institución Milà i Fontanals, pp. 55-106.

Favier, Jean (2006), Les Papes d'Avignon, París, Fayard.

Finke, Heinrich (1907), Papstum und Untergang des Templerdordens, Münster, Verlag der Aschendorffschen buchh.

Frale, Barbara (2006), L'interrogatorio ai Templari nella Provincia di Bernardo Gui: un'ipotesi per il frammento del Registro Avignonese 305, en Dall'Archivio Segreto Vaticano. Miscellanea di testi, saggi e inventari, vol. I, Ciudad del Vaticano, Archivio Segreto Vaticano, pp. 199-272.

García de la Torre, Julián (2007), L'Ordre del Temple a Mallorca (1230-1312), Palma de Mallorca, Associació Domus Templi.

Göller, Emil (1910), Die Einnahmen der Apostolischen Kammer unter Johann $X I I$, Paderborn, Schöninch.

Guillemain, Bernard (1962), La cour pontificale d'Avignon (1309-1376). Étude d'une société, París, E. de Boccard.

Guillemain, Bernard (1998), Les papes d'Avignon (1309-1376), París, Éditions du Cerf.

Hayez, Anne Marie (2007), La rétribution des officiers et familiers des Papes au XIVé siècle, en Offices, écrit et papauté (XIII ${ }^{e}-X V I I I^{e}$ siècle), Roma, École Française de Rome, pp. 427-443.

Hoberg, Hermann (1969), Taxae pro comunibus servitiis, ex libris Obligationum ab anno 1295 usque ad annum 1455 confectis, Ciudad del Vaticano, Archivio Segreto Vaticano.

Javierre Mur, Áurea Lucinda (1961), Aportación al estudio del proceso contra el Temple en Castilla, "Revista de Archivos, Bibliotecas y Museos" 69, pp. 47-100.

Ladero Quesada, Miguel Ángel (2001), Historia de la Iglesia en la España Medieval, en La historia de la Iglesia en España y el mundo hispano, Murcia, Ed. Univ. Católica de San Antonio de Murcia, pp. 121-190.

Lagarde, Georges de (1934), La naissance de l'esprit laïque au déclin du Moyen Age, Saint-Paul-Trois-Château, Éditions Béatrice.

Lizerand, Georges (1910), Clément V et Philippe le Bel, París, Hachette.

Martínez Díez, Gonzalo (1993), Los templarios en la Corona de Castilla, Burgos, La Olmeda.

Miret y Sans, Joaquim (1911), Inventari de les cases del Temple de la Corona d'Aragó, "Boletín de la Real Academia de las Buenas Letras de Barcelona" 2, pp. 61-75.

Mitre Fernández, Emilio (2003), La Iglesia en la Edad Media. Una introducción histórica, Madrid, Ed. Síntesis.

Mollat, Guillaume (1921), La collation des bénéfices ecclésiastiques sous les 
papes d'Avignon (1305-1378), París, Boccard.

Mollat, Guillaume (1949), Les papes d'Avignon. 1305-1378, París, Letouzey \& Ané.

Mossé, Claude y Pallanchard, Nicole (1998), Clément V, premier pape d'Avignon (1265-1314), París, Stock.

Müller, Edwald (1934), Das Konzil con Vienne. 1311-1312. Seine Quellen und seine Geschichte, Münster, Aschendorff.

Nadal Cañellas, Juan (2010), La abolición de la orden del Temple y su gestación, "Bolletí de la Societat Arqueològica Lul·liana: Revista d'Estudis Històrics" 66, pp. 35-50.

Nieto Soria, José Manuel (1988), Iglesia y poder real en Castilla: el episcopado, 1250-1350, Madrid, Universidad Complutense.

Nieto Soria, José Manuel (1996), El pontificado medieval, Madrid, Arco Libros.

Orlandis Rovira, José (1989), Historia de la Iglesia. I. La Iglesia Antigua y Medieval, Madrid, Editorial Palabra (6. ${ }^{\text {a }}$ edición).

Paladilhe, Dominique (1975), Les Papes en Avignon, París, Fayard.

Pujol, Alain (1988) Clément V, le Pape maudit, Burdeos, La Brede.

Raynaldo, Odorico (1747), Annales ecclesiastici, ab anno MCXVIII ubi desinit cardinalis Baronius, Lucca, Typis Leonardi Venturini.

Renouard, Yves (1954), La papauté à Avignon, París, Presses Universitaires de France.

Rivière, Jacques (1926), Le problème de l'Église et de l'État au temps de Philippe le Bel, Lovaina - París, Bureaux du "Spicilegium Sacrum Lovaniense" Champion.

Sans i Travé, Josep Maria (1991), Els Templers catalans. De la rosa a la creu, Lérida, Pagès Editors.

Schenk Sanchís, Juan E. (1979), El traslado de Roma a Avignon: Clemente V, en Historia de la Iglesia. XI. Centralización pontificia y tendencias nacionales, Valencia, Edicep, pp. 192-262.

Theis, Valérie (2006), La réforme comptable de la Chambre apostolique et sus acteurs au début du XIVe siécle, "Mélanges de l'École Française de Rome (Moyen Âge)" 188/2, pp. 169-182.

Vilar y Bonet, María (1962), Actividades financieras del Temple en la Corona de Aragón, en VI Congreso de Historia de la Corona de Aragón, vol. II, Barcelona, Editorial del Instituto Jerónimo Zurita, pp. 577-583.

Fecha de recepción del artículo: julio 2020

Fecha de aceptación y versión final: marzo 2021 